\title{
Angiotensin-I-converting enzyme inhibitory peptides in milk fermented by indigenous lactic acid bacteria
}

\author{
Yuliana Tandi Rubak ${ }^{1}$, Lilis Nuraida ${ }^{1,2}$, Dyah Iswantini ${ }^{3}$ and Endang Prangdimurti ${ }^{1}$
}

1. Department of Food Science and Technology, Food Science Study Program, IPB University (Bogor Agricultural University), Bogor, Indonesia; 2. Southeast Asian Food and Agricultural Science and Technology Center, IPB University (Bogor Agricultural University), Bogor, Indonesia; 3. Department of Chemistry; and Tropical Biopharmaca Research Center, IPB University (Bogor Agricultural University), Bogor, Indonesia.

Corresponding author: Lilis Nuraida, e-mail: Inuraida@gmail.com

Co-authors: YTR: rubakyuliana@yahoo.co.id, DI: dyahprado@gmail.com,EP: e_prangdimurti@yahoo.com Received: 08-10-2019, Accepted: 31-12-2019, Published online: 21-02-2020

doi: www.doi.org/10.14202/vetworld.2020.345-353 How to cite this article: Rubak YT, Nuraida L, Iswantini D, Prangdimurti E (2020) Angiotensin-I-converting enzyme inhibitory peptides in milk fermented by indigenous lactic acid bacteria, Veterinary World, 13(2): 345-353.

\begin{abstract}
Background and Aim: Fermented milk can be used to produce antihypertensive peptides. Lactic acid bacteria (LAB) with its proteolytic system hydrolyze milk protein during fermentation to produce several peptides, which include antihypertensive bioactive peptides. This study aimed to investigate the ability of indigenous LAB for the production of angiotensin-Iconverting enzyme inhibitory (ACE-I) peptides in fermented milk and to characterize the ACEI peptides.

Materials and Methods: Reconstituted milk (11\%) inoculated with ten LAB isolates, and then incubated at $37^{\circ} \mathrm{C}$ until it reaches $\mathrm{pH}$ 4.6. The evaluation was carried out for LAB count, lactic acid concentration, peptide content, and ACE-I activity. The low molecular weight (MW) peptides $(<3 \mathrm{kDa})$ were identified using Nano LC Ultimate 3000 series system Tandem Q Exactive Plus Orbitrap high-resolution mass spectrometry.

Results: The result showed that the ten LAB isolates were able to produce ACE-I in fermented milk with the activities in the range of $22.78 \pm 2.55-57.36 \pm 5.40 \%$. The activity of ACE-I above $50 \%$ produced by Lactobacillus delbrueckii BD7, Lactococcus lactis ssp. lactis BD17, and Lactobacillus kefiri YK4 and JK17, with the highest activity of ACE-I produced by L. kefiri YK4 $\left(\mathrm{IC}_{50} 0.261 \mathrm{mg} / \mathrm{mL}\right)$ and $L$. kefiri JK17 $\left(\mathrm{IC}_{50} 0.308 \mathrm{mg} / \mathrm{mL}\right)$. Results of peptide identification showed that L. kefiri YK 4 could release as many as 1329 , while L. kefiri JK 17 could release 174 peptides. The peptides produced were $95 \%$ derived from casein. The other peptides were from ó-lactalbumin, $\beta$-lactoglobulin, and serum amyloid A. The peptides produced consisted of 6-19 amino acid residues, with MWs of 634-2079 Dalton and detected at 317-1093 m/z. A total of 30 peptides have been recognized based on literature searches as ACE-I peptides (sequence similarity: $100 \%$ ).
\end{abstract}

Conclusion: L. kefiri YK4 and JK17 are the potential to be used as starter cultures to produce the bioactive peptide as ACE-I in fermented milk.

Keywords: angiotensin-I-converting enzyme inhibitory peptides, fermented milk, indigenous lactic acid bacteria, Lactobacillus kefiri.

\section{Introduction}

Fermented milk has been proven to improve and maintain human health. It relates to the biological activities found in fermented milk, such as antioxidant, immunomodulatory, anti-inflammatory, antibacterial, anticancer, and antihypertensive activities [1-4]. Antihypertensive activity of fermented milk is one of the interesting areas due to the increases of hypertension cases and side effects caused by the use of synthetic drugs such as captopril, lisinopril, and enalapril [5]. Angiotensin-I-converting enzyme (ACE, EC 33.4.15.1, CD143) plays a key role in the blood pressure regulation system. ACE converts inactive decapeptide

Copyright: Rubak, et al. Open Access. This article is distributed under the terms of the Creative Commons Attribution 4.0 International License (http://creativecommons.org/licenses/by/4.0/), which permits unrestricted use, distribution, and reproduction in any medium, provided you give appropriate credit to the original author(s) and the source, provide a link to the Creative Commons license, and indicate if changes were made. The Creative Commons Public Domain Dedication waiver (http://creativecommons.org/ publicdomain/zero/1.0/) applies to the data made available in this article, unless otherwise stated.
Angiotensin I to the potent vasoconstrictor, i.e., the octapeptide Angiotensin II and also inactivates bradykinin, a vasodilator $[6,7]$. ACE is one of the effective targets to reduce blood pressure. ACE-inhibitory (ACE-I) peptides can be isolated from fermented milk and are a safe, natural source to be used in the treatment of hypertension. Milk protein is a precursor of bioactive peptides [8-10], but most of the peptides in milk are inactive that requiring hydrolysis to release them. Fermentation of milk involving lactic acid bacteria (LAB) such as in yogurt, cheese, and other fermented milk is a method known to hydrolyze proteins and release bioactive peptides from the primary protein structure $[11,12]$. The proteolytic system makes $\mathrm{LAB}$ as a prospective producer of bioactive antihypertensive peptides in fermented food products $[13,14]$. Proteolytic activity of $\mathrm{LAB}$ varies between species and even strains. Therefore, it is necessary to find a LAB with high proteolytic activity to produce bioactive antihypertensive peptide. The LAB which has been reported by several researchers as being able to produce bioactive antihypertensive peptides 
in fermented milk among others are Lactobacillus helveticus [13,15], Lactobacillus plantarum, Lactobacillus pentosus, Pediococcus acidilactici, Pediococcus pentosaceus, Lactobacillus delbrueckii ssp. bulgaricus, and Lactococcus lactis $[16,17]$. L. helveticus has been widely used in dairy products to generate ACE-I peptides [18]. Calpis, which is a soft drink manufactured in Japan, is produced from milk fermented by a mixture of L. helveticus CP790 and Saccharomyces cerevisiae [19]. Two bioactive peptides with ACE-I activity have been identified in calpis, i.e., Val-Pro-Pro (VPP) and Ile-Pro-Pro (IPP). VPP and IPP peptides have the same structure as captopril and enalapril [20] commonly used in hypertension therapy [21].

Screening of LAB capable of producing bioactive peptides as ACE-I and characterization of the resulted peptides are essential to obtain isolates that can be used as starter cultures to produce fermented milk containing antihypertensive peptides. The availability of indigenous LAB with the ability to produce specific peptides as a starter culture will also contribute to the diversification of fermented milk products as a functional food.

This study aimed to explore the capacity of ten indigenous $\mathrm{LAB}$ that previously has been isolated from tempe, kefir, and breast milk to generate ACE-I peptides and to characterize the ACE-I peptides generated.

\section{Materials and Methods \\ Ethical approval}

No animals were used in the present study, so there was no requirement of ethical approval.

\section{LAB}

The ten LAB were $P$. pentosaceus 1 W2SR04, $L$. plantarum 1 W22408, Lactobacillus rhamnosus R2, Lactobacillus R7F, L. delbrueckii BD7, L. lactis ssp. lactis BD17, Lactobacillus fermentum R6, S206, and Lactobacillus kefiri YK4 and JK17 that previously have been isolated from tempe, kefir, and breast milk were obtained from Food Microbiology Laboratory of the Southeast Asian Food and Agricultural Science and Technology (SEAFAST) Center, IPB University, Bogor, Indonesia.

\section{Fermentation of milk}

The $\mathrm{LAB}$ isolates were refreshed by growing them in De Man, Rogosa, and Sharpe broth (Oxoid, USA) and incubated at $37^{\circ} \mathrm{C}$ for $24 \mathrm{~h}$. To prepare inoculum for milk fermentation, the isolates were inoculated into $11 \%$ skim milk and incubated for $24 \mathrm{~h}$ at $37^{\circ} \mathrm{C}$. The starter culture $(2 \%)$ was inoculated into pasteurized $\left(95^{\circ} \mathrm{C}\right.$ for $\left.10 \mathrm{~min}\right)$ reconstituted skim milk (11\% NZWP Ltd., NZ) and then incubated at $37^{\circ} \mathrm{C}$ to reach $\mathrm{pH} 4.6$ ( $\mathrm{pH} 700$ Eutech). When the $\mathrm{pH}$ has been reached, the LAB count and titratable acidity were analyzed. The fermentation process was then stopped by heating at $75^{\circ} \mathrm{C}$ for $1 \mathrm{~min}$. The fermented milk was then centrifuged (Hettich, Zentrifugen, Mikro 22R) at $6000 \times \mathrm{g} 10 \mathrm{~min}$ at $4^{\circ} \mathrm{C}$. For the analysis of soluble protein, peptide, and ACE-I activity, the supernatant was collected. The titratable acidity was determined by the titration, while the LAB was enumerated on De Man, Rogosa, and Sharpe Agar (Oxoid, USA).

\section{Determination of peptide content}

The o-phthaldialdehyde (OPA) method was used to measure peptide content [22]. A total of $50 \mu \mathrm{L}$ samples were mixed with $2 \mathrm{~mL}$ of OPA reagents (consisting of $25 \mathrm{~mL}$ of $100 \mathrm{mM}$ of sodium tetraborate, $2.5 \mathrm{~mL}$ of $20 \%(\mathrm{w} / \mathrm{w})$ of sodium dodecyl sulfate, and $1.1 \mathrm{~mL}$ of OPA solution, mixed with $21.4 \mathrm{~mL}$ of $\mathrm{dH}_{2} \mathrm{O}$ ). The OPA solution was prepared by dissolving $40 \mathrm{mg}$ of OPA (Sigma, USA) in $1 \mathrm{~mL}$ of methanol $+100 \mathrm{~mL}$ of B-mercaptoethanol (Sigma, USA). The sample and OPA reagent were quickly mixed with and then incubated for $2 \mathrm{~min}$, then the sample absorbance was measured at $340 \mathrm{~nm}$ (UV-VIS-1240, Shimadzu, Kyoto, JPN). The peptide content was quantified using the tryptone casein (Merck, USA) standard curve.

\section{Determination of soluble protein content}

Protein content was determined using the Bradford method [23]. A total of $10 \mu \mathrm{L}$ samples were mixed with $250 \mu \mathrm{L}$ Bradford reagent and then incubated for $5 \mathrm{~min}$. The absorbance of the sample was measured at $595 \mathrm{~nm}$ (Biorad, iMark, Microplate Reader, JPN). The protein content of the sample was calculated using a standard curve of bovine serum albumin (Sigma, USA).

\section{Determination of ACE-I activity}

The determination of ACE-I activity was performed in vitro based on the method of Chusman and Cheung [24]. Hippuryl-L-Histidyl-L-Leucine (HHL, Sigma, USA) was used as the enzyme-substrate. A 50 $\mu \mathrm{L}$ of the substrate $(50 \mathrm{mM}$ HHL in $0.1 \mathrm{M}$ sodium borate buffer containing $0.3 \mathrm{M} \mathrm{NaCl}$ at $\mathrm{pH} 8.3$ ) was added into $50 \mu \mathrm{L}$ sample and incubated at $37^{\circ} \mathrm{C}$ for $5 \mathrm{~min}$. To initiate the reaction, $50 \mu \mathrm{L}$ of $0.1 \mathrm{U} / \mathrm{mL}$ ACE (Sigma, USA) solution was added, and the mixture was incubated at $37^{\circ} \mathrm{C}$ for $5 \mathrm{~min}$. The reaction was stopped by adding $250 \mu \mathrm{L} 1 \mathrm{M} \mathrm{HCl} 1 \mathrm{M}$. The resulted in hippuric acid (HA) was extracted with $1.5 \mathrm{~mL}$ ethyl acetate and centrifuged at $2000 \times \mathrm{g}$ for $5 \mathrm{~min}$. An aliquot $(0.8 \mathrm{~mL})$ of the ethyl acetate layer was transferred to a clean tube and evaporated at $85^{\circ} \mathrm{C}$ for $60 \mathrm{~min}$. Distilled water $(4 \mathrm{~mL})$ was then added to dissolve the HA in the tube, and the amount of HA formed was measured by measuring optical density at $228 \mathrm{~nm}$ (UV-2800, Hitachi, JPN) The extent of inhibition was calculated as $100 \%([\mathrm{~B}-\mathrm{A}] / \mathrm{B})$ where $\mathrm{A}$ is the optical density in the presence of ACE and ACE-I component, $\mathrm{B}$ is the optical density without ACE-I component.

\section{IC $_{50}$ value}

The value of $\mathrm{IC}_{50}$ was calculated based on the equation obtained from the curve of ACE inhibition 
as a function of different concentrations of peptide. The value of $\mathrm{IC}_{50}$ is defined as the amount of peptide required to inhibit $50 \%$ of ACE activity.

\section{Characterization of peptides from fermented milk Partial purification}

The supernatant of fermented milk that has the highest ACE-I activity was pipetted into ultrafiltration centrifuge tubes molecular weight (MW) cutoff of $3 \mathrm{kDa}$ (Merck, Amicon Ultra-4 mL, Centrifugal Filters, IRL). We collected two fractions (MW $<3 \mathrm{kDa}$ and $\mathrm{MW}>3 \mathrm{kDa}$ ) and assayed their ACE-I activity.

\section{Identification of peptides by mass spectrometry (MS)}

The characterization of peptide (MWs and amino acid sequences) was carried out in Advanced Research Laboratory, IPB University (Bogor Agricultural University) based on the method of Daliri et al. [25] using Nano Liquid Chromatography (LC) Ultimate 3000 series system Tandem Q Exactive Plus Orbitrap high-resolution MS (Thermo Scientific, GER). Fractions $<3 \mathrm{kDa}(5 \mu \mathrm{L})$ of the samples were injected into the LC-nano MS system. The samples were trapped on a trap column (Thermo Scientific, $164649,30 \mu \mathrm{m} \times 5 \mathrm{~mm}$ ) and washed for 6 min with gradient with $98 \%$ Solvent A (water/acetonitrile [98:2, $\mathrm{v} / \mathrm{v}], 0.1 \%$ formic acid) and 2\% Solvent B (Water/acetonitrile $[2: 98, \mathrm{v} / \mathrm{v}], 0.1 \%$ formic acid) at a flow rate of $5 \mu \mathrm{L} / \mathrm{min}$. The peptides were separated on a capillary column (PepMap RSLC-C18, 75- $\mu \mathrm{m} \times 150 \mathrm{~mm}$, $3.5 \mu \mathrm{m}$ particle size, 100 pore size, part number ES 800 , Thermo Scientific) at a flow rate of $300 \mathrm{~nL} / \mathrm{min}$ with gradient at 2-35\% Solvent B over $30 \mathrm{~min}$, then from $35 \%$ to $90 \%$ over $10 \mathrm{~min}$, followed by $90 \%$ Solvent B for $5 \mathrm{~min}$, and finally $5 \%$ Solvent B for $15 \mathrm{~min}$. Electrospray was performed at an ion spray voltage of $3500 \mathrm{eV}$. The range of $\mathrm{m} / \mathrm{z}$ values was 200 2000. The peptides were analyzed using Proteomic Discoverer 2.2 software.

\section{Statistical analysis}

All analyses were carried out in triplicate and expressed as mean \pm standard deviation. The data obtained were analyzed by Analysis of Variance. The differences between means were assessed using the Duncan test and were considered significant when $\mathrm{p} \leq 0.05$. Statistical analysis was performed using SPSS version 16 software (IBM Corp., NY, USA).

\section{Results}

\section{Growth of LAB in milk}

Table-1 shows the growth of LAB, titratable acidity, and fermentation time required by $10 \mathrm{LAB}$ to reach $\mathrm{pH} 4.5$. Changes in $\mathrm{pH}$ due to the accumulation of lactic acid as a result of lactose metabolism during fermentation ranged from $0.77 \pm 0.06$ to $0.91 \pm 0.06 \%$. The fermentation time required to reach $\mathrm{pH} 4.6$ by 10 LAB was $24-48 \mathrm{~h}$. The lactic acid counts ranged from $9.11 \pm 0.22$ to $9.62 \pm 0.28 \log \mathrm{CFU} / \mathrm{mL}$. The soluble protein content in the sample ranged from $0.215 \pm 0.01$ to $0.395 \pm 0.00 \mathrm{mg} / \mathrm{mL}$ (Table- 1 ).

\section{ACE-I activity}

The percentages of ACE-I activity, peptide content, and inhibitory efficiency ratio (IER) values in milk fermented by $10 \mathrm{LAB}$ cultures are shown in Table-2. ACE-I activity ranged from $22.78 \pm 2.55 \%$ to $57.36 \pm 5.40 \%$ in fermented milk. ACE-I activity above $50 \%$ was found in milk fermented by $L$. delbrueckii BD7, L. lactis ssp. lactis BD17, and L. kefiri YK4 and JK17. The highest percentage of ACE-I was obtained in milk fermented by L. kefiri YK4 and L. kefiri JK17, but it was not significantly different $(>0.05)$ with milk fermented by L. delbrueckii $\mathrm{BD} 7$ and L. lactis ssp. lactis BD17. As a positive control, captopril was used which generated ACE-I activity of $87.5 \pm 1.05 \%$.

\section{IC $_{50}$ value}

The $\mathrm{IC}_{50}$ value was measured in fermented milk with the highest activity of ACE-I (fermented milk of L. kefiri JK17 and YK4). Captopril was also measured as a control (Table- 3 ). $\mathrm{IC}_{50}$ values reflect the concentration of peptide required to inhibit 50\% ACE.

\section{Partial purification}

Results of filtration using a membrane with MW cutoff $<3 \mathrm{kDa}$ yielded two fractions, i.e., $>3 \mathrm{kDa}$ and $3 \mathrm{kDa}$ with ACE-I activity as shown in Table-4. The whole supernatant of $L$. kefiri YK4 achieved the highest ACE-I activity $(57.36 \pm 5.40 \%)$ but it was not significantly different $(>0.05)$ from the $<3 \mathrm{kDa}$ fraction (55.45 $\pm 1.97 \%)$. Meanwhile, the ACE-activity of the whole supernatant from milk fermented by L. kefiri

Table-1: Fermentation time, titratable acidity, viable count of $L A B$, and soluble protein content in fermented milk after $\mathrm{pH} 4.6$ were reached.

\begin{tabular}{|c|c|c|c|c|}
\hline Starter culture & $\begin{array}{c}\text { Fermentation time } \\
\text { (h) }\end{array}$ & $\begin{array}{c}\text { Titratable } \\
\text { acidity (\%) }\end{array}$ & $\begin{array}{c}\text { Viable LAB } \\
(\log \text { CFU/mL) }\end{array}$ & $\begin{array}{l}\text { Soluble protein content } \\
\text { ( } \mathrm{mg} / \mathrm{mL})\end{array}$ \\
\hline Lactobacillus rhamnosus R2 & 32 & $0.77 \pm 0.06$ & $9.46 \pm 0.36$ & $0.215 \pm 0.01$ \\
\hline Lactobacillus kefiri JK17 & 32 & $0.84 \pm 0.05$ & $9.62 \pm 0.40$ & $0.395 \pm 0.00$ \\
\hline Lactobacillus delbrueckii BD7 & 48 & $0.83 \pm 0.04$ & $9.41 \pm 0.25$ & $0.383 \pm 0.01$ \\
\hline Lactobacillus fermentum S206 & 48 & $0.87 \pm 0.05$ & $9.33 \pm 0.37$ & $0.277 \pm 0.01$ \\
\hline Lactobacillus kefiri YK4 & 32 & $0.91 \pm 0.06$ & $9.62 \pm 0.28$ & $0.343 \pm 0.00$ \\
\hline Lactobacillus R7F & 40 & $0.84 \pm 0.02$ & $9.11 \pm 0.22$ & $0.386 \pm 0.02$ \\
\hline Lactobacillus fermentum R6 & 24 & $0.80 \pm 0.06$ & $9.49 \pm 0.26$ & $0.384 \pm 0.01$ \\
\hline Lactobacillus plantarum 1W22408 & 32 & $0.79 \pm 0.04$ & $9.21 \pm 0.41$ & $0.277 \pm 0.01$ \\
\hline Lactococcus lactis ssp. lactis BD17 & 40 & $0.82 \pm 0.08$ & $9.25 \pm 0.42$ & $0.361 \pm 0.01$ \\
\hline
\end{tabular}

$\mathrm{LAB}=$ Lactic acid bacteria 
Table-2: ACE-inhibitory, peptide content, and IER in milk fermented by ten LAB cultures after reaching pH 4.6 incubated at $37^{\circ} \mathrm{C}$.

\begin{tabular}{lccc}
\hline Starter culture & \% inhibition of ACE & Peptide content $\mathbf{( m g / m L )}$ & IER (\% per mg/mL) \\
\hline Lactobacillus rhamnosus R2 & $22.78 \pm 2.55^{\mathrm{e}}$ & $4.012 \pm 0.20^{\mathrm{a}}$ & $5.68 \pm 0.62^{\mathrm{e}}$ \\
Lactobacillus kefiri JK17 & $56.53 \pm 1.53^{\mathrm{a}}$ & $3.976 \pm 0.17^{\mathrm{a}}$ & $14.23 \pm 0.53^{\mathrm{a}}$ \\
Lactobacillus delbrueckii BD7 & $50.97 \pm 2.46^{\mathrm{ab}}$ & $3.727 \pm 0.27^{\mathrm{ab}}$ & $13.79 \pm 1.60^{\mathrm{ab}}$ \\
Lactobacillus fermentum S206 & $40.83 \pm 3.55^{\mathrm{cd}}$ & $3.676 \pm 0.21^{\mathrm{abc}}$ & $11.12 \pm 0.84^{\mathrm{c}}$ \\
Lactobacillus kefiri YK4 & $57.36 \pm 5.40^{\mathrm{a}}$ & $3.540 \pm 0.07^{\mathrm{abcd}}$ & $16.24 \pm 1.85^{\mathrm{a}}$ \\
Lactobacillus R7F & $27.78 \pm 2.89^{\mathrm{e}}$ & $3.322 \pm 0.21^{\mathrm{bcd}}$ & $8.44 \pm 1.32^{\mathrm{d}}$ \\
Lactobacillus fermentum R6 & $44.86 \pm 1.87^{\mathrm{bc}}$ & $3.266 \pm 0.22^{\mathrm{bcd}}$ & $13.81 \pm 1.13^{\mathrm{ab}}$ \\
Lactobacillus plantarum 1W22408 & $46.94 \pm 3.42^{\mathrm{bc}}$ & $3.219 \pm 0.29^{\mathrm{de}}$ & $14.81 \pm 0.70^{\mathrm{a}}$ \\
Lactococcus lactis ssp. lactis BD17 & $52.22 \pm 4.86^{\mathrm{ab}}$ & $3.211 \pm 0.26^{\mathrm{de}}$ & $16.33 \pm 1.72^{\mathrm{a}}$ \\
Pediococcus pentosaceus 1 W2SR04 & $35.14 \pm 3.27^{\mathrm{d}}$ & $3.116 \pm 0.08^{\mathrm{e}}$ & $11.27 \pm 0.99^{\mathrm{c}}$ \\
Captopril & $87.5 \pm 1.05$ & & \\
\hline ACEAnglot & &
\end{tabular}

ACE=Angiotensin-I-converting enzyme, IER=Inhibitory efficiency ratio

Different superscripts in the same column indicates significant $(p<0.05)$ between samples

Table-3: IC $_{50}$ value of Captopril and milk fermented by Lactobacillus kefiri YK4 and Lactobacillus kefiri JK17.

\begin{tabular}{lcc}
\hline \multicolumn{3}{c}{ IC $_{\mathbf{5 0}}$ value $(\mathbf{m g} / \mathbf{m L})$} \\
\hline \multicolumn{2}{c}{ Fermented $\mathbf{~ m i l k}$} & Control \\
\hline Lactobacillus kefiri & Lactobacillus & Captopril \\
YK4 & kefiri JK17 & \\
$0.261 \pm 3.94^{\mathrm{a}}$ & $0.308 \pm 8.16^{\mathrm{b}}$ & $0.008 \pm 0.23^{\mathrm{c}}$ \\
\hline
\end{tabular}

Different superscripts in the same row indicates significant $(p<0.05)$ between samples

Table-4: ACE-I activity of supernatant, fractions of $>3$ $\mathrm{kDa}$ and $<3 \mathrm{kDa}$ in milk fermented by Lactobacillus kefiri YK4 and Lactobacillus kefiri JK17.

\begin{tabular}{lccc}
\hline \multirow{2}{*}{$\begin{array}{l}\text { Starter } \\
\text { culture }\end{array}$} & \multicolumn{3}{c}{ ACE-I activity (\%) } \\
\cline { 2 - 4 } & Supernatant & $>3 \mathbf{~ k D a}$ & $<3 \mathbf{~ k D a}$ \\
\hline $\begin{array}{l}\text { Lactobacillus } \\
\text { kefir YK4 }\end{array}$ & $57.36 \pm 5.40^{\mathrm{a}}$ & $31.89 \pm 2.08^{\mathrm{b}}$ & $55.45 \pm 1.97^{\mathrm{a}}$ \\
$\begin{array}{l}\text { Lactobacillus } \\
\text { kefiri JK17 }\end{array}$ & $56.53 \pm 1.53^{\mathrm{a}}$ & $24.03 \pm 1.64^{\mathrm{b}}$ & $52.28 \pm 4.09^{\mathrm{c}}$ \\
\hline
\end{tabular}

ACE-I=Angiotensin-I-converting enzyme inhibitor Different superscripts in the same row indicates significant $(p<0.05)$ between samples

JK17 $(56.53 \pm 1.53 \%)$ was significantly higher than both fractions of $>3 \mathrm{kDa}(24.03 \pm 1.64 \%)$ and $<3 \mathrm{kDa}$ $(52.28 \pm 4.09 \%)$.

\section{Identification of ACE-I peptides}

Peptide profile in fermented milk $(<3 \mathrm{kDa})$ by $L$. kefiri YK4 and L. kefiri JK17 is presented in Table-5. Identification of peptides in the fraction $<3 \mathrm{kDa}$ showed that the majority of peptides had $\mathrm{m} / \mathrm{z}$ values range of 317-1093 with MWs of 634-2079 Dalton, and the number of residues was 6-20 amino acids. The peptides produced from both samples were derived from the hydrolysis of the casein parent protein $(\alpha \mathrm{S} 1$-casein, $\alpha \mathrm{S} 2$-casein, $\beta$-casein, and $\kappa$-casein), $\alpha$ - lactalbumin, $\beta$-lactoglobulin, and serum amyloid A.

A total of 1329 peptides were found in the fermented milk of L. kefiri YK4 starter culture (the whole data are not presented). As much as, 95.6\% of resulted peptides were originated from casein with the proportion of $58.24 \% \beta$-casein, $27.24 \%$ $\kappa$-casein, $6.92 \% \alpha \mathrm{S} 1$-casein, and 3.16\% $\alpha \mathrm{S} 2$-casein.
Other peptides were $1.58 \% \alpha$-lactalbumin, $1.28 \%$ $\beta$-lactoglobulin, and $21.58 \%$ serum amyloid $\mathrm{A}$. The dominant peptides derived from $\beta$-casein were identified as ARHPHPHLSF and MPFPKYPVEPF (Table-5). In fermented milk supernatant of L. kefiri JK17, 174 peptides were identified (the whole data are not shown). The peptides found were $95 \%$ derived from casein with the proportion of $43 \% \alpha \mathrm{S} 1$-casein, $21.8 \% \beta$-casein, $19 \% \alpha \mathrm{S} 2$-casein, and $10.9 \%$ к-casein. Other peptides were $1.7 \%$ ó-lactalbumin and $2.9 \% \beta$-lactoglobulin. The dominant peptides found were identified as FSDIPNPIGSENSEKTTMP, FVA PFPEVFGKEK, LYQGPIVLNPWDQVKRN, and MPFPKYPVEP (Table-5).

The distribution of peptides is presented in Figure-1. Based on the type of peptide, 480 different peptides were found in samples with starter culture $L$. kefiri YK4 and 110 peptides in samples with starter culture $L$. kefiri JK17. A total of 27 similar peptides were found in both samples.

The identification of peptides with ACE-I activity was performed by searching the peptides that have been reported in the literature. Table- 6 shows the peptides that were reported to have ACE-I activity. The ACE-I peptides presented in Table- 6 are only homologous peptides (sequence similarity: 100\%) to the peptides that have been reported to have ACE-I activity [26-43].

\section{Discussion}

During milk fermentation by $\mathrm{LAB}$, the bacteria ferment lactose into organic acid, mainly lactic acid, and bring the $\mathrm{pH}$ down. The time to reach $\mathrm{pH} 4.6$ varied between LAB showing the difference in the rate of growth. Short fermentation time $(24 \mathrm{~h})$ was observed in milk fermented by P. pentosaceus $1 \mathrm{~W} 2 \mathrm{SR} 04$ and L. fermentum R6, while the longest fermentation time (48 hours) occurred in milk fermented by L. delbrueckii BD7 and L. fermentum S206. A previous study by Chen et al. [13] report that the time to reach a $\mathrm{pH}$ of 4.6 by 37 Lactobacillus varied from 7 to $42.4 \mathrm{~h}$. Meanwhile, L. delbrueckii QS306 required incubation time of $48 \mathrm{~h}$ to reach a $\mathrm{pH}$ of less than 4.7 [44]. 
Table-5: Fermented milk peptide profile ( $<3 \mathrm{kDa}$ ) of Lactobacillus kefiri YK4 and Lactobacillus kefiri JK17.

\begin{tabular}{|c|c|c|c|c|c|c|}
\hline Parent protein & $\begin{array}{l}\text { Peptide } \\
\text { total }\end{array}$ & $\begin{array}{c}\text { Range of } \\
\text { precursor } \mathrm{m} / \mathrm{z}\end{array}$ & $\begin{array}{c}\text { Range of } \\
\text { precursor MW }\end{array}$ & $\begin{array}{l}\text { Amino acid } \\
\text { residue }\end{array}$ & Dominant peptide & LAB \\
\hline \multirow[t]{2}{*}{$\alpha \mathrm{S} 1$-casein } & 92 & $374-971$ & $747-1941$ & $6-18$ & FSDIPNPIGSE & YK 4 \\
\hline & 76 & $438-1040$ & $876-2079$ & $7-19$ & $\begin{array}{l}\text { FSDIPNPIGSENSEKTTMP, } \\
\text { FVAPFPEVFGKEK }\end{array}$ & JK 17 \\
\hline \multirow[t]{2}{*}{$\alpha \mathrm{S} 2$-casein } & 42 & $325-882$ & $810-1763$ & $6-15$ & QGPIVLNPWDQVKR & YK 4 \\
\hline & 33 & $424-680$ & $848-2040$ & $7-17$ & LYQGPIVLNPWDQVKRN & JK 17 \\
\hline \multirow[t]{2}{*}{$\beta$-casein } & 774 & $327-1093$ & $979-2185$ & $6-18$ & MPFPKYPVEPF & YK 4 \\
\hline & 38 & $317-1022$ & $634-2044$ & $6-19$ & MPFPKYPVEP & JK 17 \\
\hline \multirow[t]{2}{*}{$\kappa$-casein } & 362 & $300-954$ & $841-2038$ & $6-18$ & ARHPHPHLSF & YK 4 \\
\hline & 19 & $324-889$ & $924-1777$ & $7-18$ & $\begin{array}{l}\text { FMAIPPKKNQD, } \\
\text { VRSPAQILQ }\end{array}$ & JK 17 \\
\hline \multirow[t]{2}{*}{$\alpha$ - lactalbumin } & 21 & $400-750$ & 808-1499 & $7-13$ & KVGINYWLÄH, FHTSGYDTQ & YK 4 \\
\hline & 3 & 563 & 1126 & 10 & FHTSGYDTQA & $\mathrm{JK} 17$ \\
\hline \multirow[t]{2}{*}{$\beta$-lactoglobulin } & 17 & $322-727$ & $775-1453$ & $7-13$ & KALPMHIR & YK 4 \\
\hline & 5 & $382-622$ & $802-1243$ & $7-11$ & & JK 17 \\
\hline serum amyloid $A$ & 21 & $242-727$ & $998-1753$ & $8-15$ & EWGRSGKDPNHFRPA & YK 4 \\
\hline
\end{tabular}

A=Alanine (Ala), C=Cysteine (Cys), D=Aspartic acid (Asp), E=Glutamic acid (Glu), F=Phenylalanine (Phe), G=Glycine (Gly), $\mathrm{H}=$ Histidine (His), I=Isoleucine (Ile), $\mathrm{K}=$ Lysine (Lys), L=Leucine (Leu), M=Methionine (Met), N=Asparagine (Asn), $\mathrm{P}=$ Proline (Pro), $\mathrm{Q}=$ Glutamine (Gln), $\mathrm{R}=$ Arginine (Arg), $\mathrm{S}=$ Serine (Ser), $\mathrm{T}=$ Threonine (Thr), $\mathrm{V}=$ Valine (Val), $W=$ Tryptophan (Trp), $Y=$ Tyrosine (Tyr)

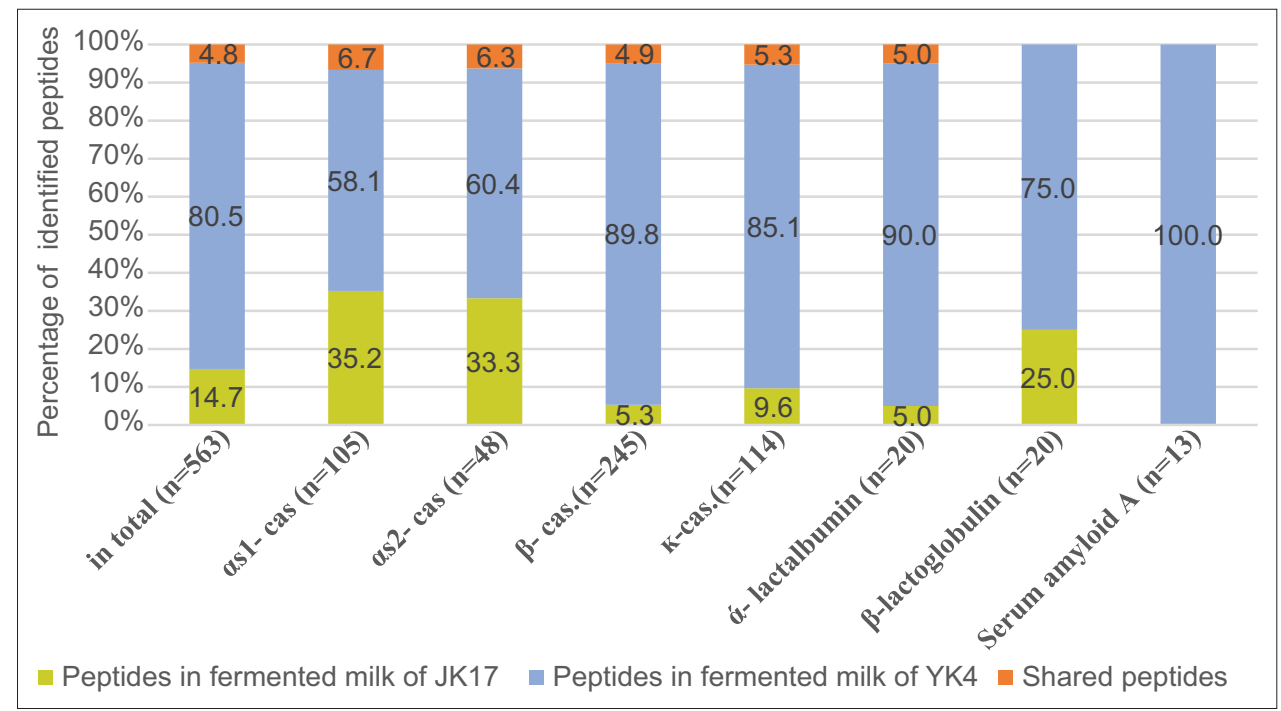

Figure-1: Distribution of identified peptides in fermented milk of Lactobacillus kefiri YK4 and JK17 in total peptides and for all parent protein, i.e., $\alpha \mathrm{S} 1-, \alpha \mathrm{S} 2, \beta$ - and $\kappa$-casein, $\alpha$-lactalbumin, $\beta$-lactoglobulin, and amyloid $\mathrm{A}$.

All LAB isolates grew well during fermentation, with a population of more than $9 \log$ CFU/mL (Table-1). A similar result of a viable count of LAB in fermented milk was reported by Elkhtab et al. [45] that of eight LAB dominated by Lactobacillus in fermented milk reached the population of $9.5 \log \mathrm{CFU} / \mathrm{mL}$ after $72 \mathrm{~h}$ incubation. Similarly, in the fermented milk of $L$. delbrueckii ssp. bulgaricus 1466 , the population reached $>8 \log \mathrm{CFU} / \mathrm{mL}$ when the fermented milk reaches a $\mathrm{pH} 4.5$ [46].

The LAB also hydrolyzes protein in milk into peptides and amino acids to support their growth. Protein hydrolysis by LAB produces bioactive peptides acting as ACE-Is. The activity of ACE-I produced in fermented milk varies between LAB fermenting the milk [21,42] and is strain-specific [47]. L. delbrueckii and L. lactis isolates that produce high ACE-I activity in this study were similar to the previous report by
Wu et al. [48] that $L$. delbrueckii strain QS306 could produce $75.58 \pm 1.69 \%$ of ACE-I activity in fermented milk and L. lactis ADP strains Q1, Q2, and Q5 could produce $90-98 \%$ of ACE-I activity after $48 \mathrm{~h}$ fermentation [49]. Meanwhile, the ACE-I activity in milk fermented by L. kefiri that isolated from kefir has not been reported.

ACE-I activity produced in fermented milk is associated with LAB's proteolytic activity. LAB's proteolytic activity generates several peptides. The peptides produced in this study ranged from $3.116 \pm 0.08$ to $4.012 \pm 0.20 \mathrm{mg} / \mathrm{mL}$. The highest peptide content was produced in milk fermented by L. rhamnosus R2 and $L$. kefiri JK17, but it was not significantly different from milk fermented by L. delbrueckii BD7, L. kefiri YK4, and L. fermentum S206. A high proteolytic activity has been reported in Lactobacillus 
Table-6: ACE-I peptides produced in fermented milk using Lactobacillus kefiri YK4 and JK17 as starter culture compared to ACE-I peptides as reported in the literature.

\begin{tabular}{|c|c|c|c|c|c|c|}
\hline \multirow{2}{*}{$\begin{array}{l}\text { Parent } \\
\text { protein }\end{array}$} & \multirow[t]{2}{*}{ Sequence peptide } & \multirow[t]{2}{*}{$\mathrm{m} / \mathbf{z}[\mathrm{Da}]$} & \multirow[t]{2}{*}{$\mathrm{MH}+[\mathrm{Da}]$} & \multirow[t]{2}{*}{ Charge } & \multicolumn{2}{|c|}{ ACE-I peptides based on literature } \\
\hline & & & & & Sequence & References \\
\hline K-casein & ARHPHPHLSFM & 443.89 & 1329.66 & 3 & ARHPHPHLSFM & {$[26]$} \\
\hline$\beta$-casein & DELQDKIHPF & 621.31 & 1241.61 & 2 & DELQDKIHPF & [27] \\
\hline$\beta$-casein & DKIHPF & 378.71 & 756.41 & 2 & DKIHPF & [28] \\
\hline$\beta$-casein & DKIHPFAQ & 478.25 & 955.50 & 2 & DKIHPFAQ & [29] \\
\hline$\beta$-casein & ELQDKIHPF & 563.80 & 1126.59 & 2 & ELQDKIHPF & {$[28]$} \\
\hline$\beta$-casein & EMPFPKYPVEPF & 740.86 & 1480.72 & 2 & EMPFPKYPVEPF & [30] \\
\hline \multirow[t]{2}{*}{ aS1-casein } & FVAPFPEV & 453.24 & 905.48 & 2 & FVAPFPEV & [31] \\
\hline & & & & & FVAPFPEV & [32] \\
\hline \multirow{2}{*}{ aS1-casein } & FVAPFPEVFG & 555.29 & 1109.57 & 2 & FVAPFPEVFG & [30] \\
\hline & & & & & FVAPFPEVFG & [32] \\
\hline aS1-casein & FVAPFPEVFGK & 619.33 & 1237.66 & 2 & FVAPFPEVFGK & [33] \\
\hline aS1-casein & FVAPFPEVFGKE & 683.85 & 1366.70 & 2 & FVAPFPEVFGKE & {$[31]$} \\
\hline$\beta$-casein & GPVRGPFPI & 470.27 & 939.54 & 2 & GPVRGPFPI & [34] \\
\hline aS1-casein & IGSENSEKTTMP & 647.30 & 1293.60 & 2 & IGSENSEKTTMP & {$[35]$} \\
\hline$\beta$-casein & LGPVRGPFP & 470.27 & 939.54 & 2 & LGPVRGPFP & {$[36]$} \\
\hline$\beta$-casein & LVYPFPGPIHNSLPQ & 839.95 & 1678.89 & 2 & LVYPFPGPIHNSLPQ & [30] \\
\hline$\beta$ - casein & LVYPFPGPIHNSLPQN & 896.97 & 1792.93 & 2 & LVYPFPGPIHNSLPQN & {$[3]$} \\
\hline$\beta$-casein & LYQEPVLGPVRGPFPIIV & 997.58 & 1994.14 & 2 & LYQEPVLGPVRGPFPIIV & {$[31]$} \\
\hline$\beta$-casein & MPFPKYPVEP & 602.80 & 1204.60 & 2 & MPFPKYPVEP & [35] \\
\hline$\beta$-casein & MPFPKYPVEPF & 676.34 & 1351.67 & 2 & MPFPKYPVEPF & [37] \\
\hline \multirow[t]{2}{*}{$\beta$-casein } & QEPVLGPVRGPFP & 696.88 & 1392.76 & 2 & QEPVLGPVRGPFP & [36] \\
\hline & & & & & QEPVLGPVRGPFP & [38] \\
\hline \multirow[t]{2}{*}{$\beta$-casein } & QEPVLGPVRGPFPIIV & 859.50 & 1718.00 & 2 & QEPVLGPVRGPFPIIV & [39] \\
\hline & & & & & QEPVLGPVRGPFPIIV & {$[40]$} \\
\hline$\beta$-casein & RDMPIQAF & 489.25 & 977.49 & 2 & RDMPIQAF & [41] \\
\hline aS1-casein & RPKHPIKH & 338.21 & 1012.61 & 3 & RPKHPIKH & [29] \\
\hline$\beta$-casein & SQSKVLPVPQ & 541.81 & 1082.62 & 2 & SQSKVLPVPQ & [35] \\
\hline aS1-casein & VAPFPEVFGK & 545.80 & 1090.59 & 2 & VAPFPEVFGK & [38] \\
\hline aS1-casein & VAPFPEVFGKE & 610.32 & 1219.63 & 2 & VAPFPEVFGKE & [32] \\
\hline$\beta$-casein & VLGPVRGPFP & 519.81 & 1038.61 & 2 & VLGPVRGPFP & [42] \\
\hline$\beta$-casein & YPFPGPIPN & 501.26 & 1001.51 & 2 & YPFPGPIPN & [43] \\
\hline$\beta$-casein & YQEPVLGPVR & 579.32 & 1157.63 & 2 & YQEPVLGPVR & {$[43]$} \\
\hline$\beta$-casein & YQEPVLGPVRGPFPI & 556.98 & 1668.91 & 3 & YQEPVLGPVRGPFPI & [33] \\
\hline \multirow[t]{2}{*}{$\beta$-casein } & YQEPVLGPVRGPFPIIV & 941.03 & 1881.06 & 2 & YQEPVLGPVRGPFPIIV & [31] \\
\hline & & & & & YQEPVLGPVRGPFPIIV & [33] \\
\hline
\end{tabular}

$A=$ Alanine (Ala), C=Cysteine (Cys), D=Aspartic acid (Asp), E=Glutamic acid (Glu), F=Phenylalanine (Phe), G=Glycine (Gly), $\mathrm{H}=$ Histidine (His), I=Isoleucine (Ile), $\mathrm{K}=$ Lysine (Lys), L=Leucine (Leu), M=Methionine (Met), $N=$ Asparagine (Asn), $\mathrm{P}=$ Proline (Pro), $\mathrm{Q}=$ Glutamine ( $\mathrm{Gln}), \mathrm{R}=$ Arginine (Arg), $\mathrm{S}=$ Serine (Ser), $\mathrm{T}=$ Threonine (Thr), $\mathrm{V}=\mathrm{Valine}(\mathrm{Val})$, $W=$ Tryptophan (Trp), $Y=$ Tyrosine (Tyr)

species. The report has led to the widespread use of Lactobacillus species for the production of antihypertensive peptides (ACE-Is) [41,50] in the fermented milk industry, such as sour milk and yogurt.

The peptide content, however, does not always correlate with the activity of ACE-I. The results obtained in this research show a poor correlation between peptide content and ACE-I activity (Table-2). Similar results were also obtained by Chen et al. [13], where the percentage of ACE-I showed a poor correlation with the amount of free amino acid in fermented milk of $L$. helveticus. Similar results were also observed in milk fermented by Leuconostoc mesenteroides 356 [3,51]. Each LAB will produce different pieces of the peptide with its specific proteolytic system. Bioactive peptides with the potential of ACE-I are specific peptides. The peptide type determines the activity of ACE-Is. However, high proteolytic activity is needed to produce several bioactive peptides in fermented milk, including the bioactive ACE-I peptide.
The value of IER ranged from $5.68 \pm 0.62$ to $16.33 \pm 1.72$. The value of IER represents the effectiveness of peptide in inhibiting ACE activity. The value of IER is obtained by dividing the percentage of ACE-I activity by peptide content. High IER values indicate inhibitory efficiency against ACE. The highest IER value was obtained in milk fermented by L. lactis ssp. lactis BD17, but the difference was not significant $(>0.05)$ than milk fermented by L. kefiri YK4, L. kefiri JK17, and L. plantarum 1 W22408.

Fermented milk of $L$. kefiri YK4 had a lower $\mathrm{IC}_{50}$ value than fermented milk of $L$. kefiri JK $17 . \mathrm{IC}_{50}$ values obtained from both samples were still lower with that of reported by Qian et al. [52] who used $L$. delbrueckii ssp. bulgaricus LB to ferment milk and resulted in the $\mathrm{IC}_{50}$ values of $67.71 \pm 7.62 \mathrm{mg} / \mathrm{mL}$; Moslehishad et al. [53] used L. rhamnosus PTCC 1637 with the $\mathrm{IC}_{50}$ value of $3.947 \pm 0.029 \mathrm{mg} / \mathrm{mL}$; and Chen et al. [54] in koumiss with $\mathrm{IC}_{50}$ of $52.47 \pm 2.87 \mathrm{mg} / \mathrm{mL}$. 
After partial purification using membrane filtration $3 \mathrm{kDa}$, the activity ACE-I of $<3 \mathrm{kDa}$ fraction of L. kefiri YK4 was not significantly different from the whole extract, but significantly higher than the fraction of $>3 \mathrm{kDa}$. This finding indicated that the active peptides were mainly at $<3 \mathrm{kDa}$. The $3 \mathrm{kDa}$ filtration is a widely used and effective way of obtaining and identifying ACE-I peptides, as ACE-I activity is produced mainly by peptides with $<3 \mathrm{kDa}$ fractions $[26,42,55]$. However, the whole supernatant of L. kefiri JK17 was significantly higher than its $<3 \mathrm{kDa}$ fraction. This result is similar to the results of Chen et al. [54] that koumiss fermented milk supernatant had a higher ACE-I activity compared to the $<3 \mathrm{kDa}$ fraction.

The dominant proteins hydrolyzed by $L$. kefiri YK4 were $\beta$-casein and $\alpha$ 1-casein by L. kefiri JK 17 (Table-5). This finding explains the difference between the two strains in the proteolytic system. The hydrolysis of non-casein proteins (ó-lactalbumin, $\beta$-lactoglobulin, and serum amyloid A) also showed that both isolates had high proteolytic activity. Some LAB such as Bifidobacterium and others are known to produce peptides only from casein. Peptides that have ACE-I activity (Table-6) are generally originated from $\beta$-casein, $\alpha \mathrm{S} 1$-casein, and K-casein. L. kefiri YK4 hydrolyzed 362 peptides from $\mathrm{K}$-casein in fermented milk. K-casein is glycomacropeptides consisting of glycine chains reported in several studies that are heavily hydrolysis-resistant [56]. This resistance was related to the presence of hydrophilic amino acids and negative charges.

ACE-I activity was related to the structure of the peptide [57]. A total of 21 ACE-I peptides obtained from the present research (Table-6) are peptides that have amino acid proline residues in the C-terminal chain. Residues of tripeptide amino acids, such as proline in the C-terminal chain, play a significant part in binding to the active side ACE [57]. In addition to proline, phenylalanine amino acid residue was also identified in 19 ACE-I peptides in the C-terminal chain. Residues of lysine amino acid were also found in five peptides of ACE-I (Table-6).

In this study (Table-6), the peptide ACE-I has a residue of 6-16 amino acids with an MW of $<2 \mathrm{kDa}$. Some researchers have previously reported that ACE-I bioactive peptides are generally short peptides with residues of 2-6 amino acids $[58,59]$ or longer peptides with 9-16 amino acids $[4,60]$ even up to 20 amino acid residues $[30,61]$.

\section{Conclusion}

The ten LAB isolates produced ACE-I activity in fermented milk. The activity of ACE-I above $50 \%$ was obtained in milk fermented by $L$. delbrueckii BD7, L. lactis ssp. lactis BD17, and L. kefiri YK4 and JK17. The highest activity of ACE-I was found in milk fermented by L. kefiri YK4 $\left(\mathrm{IC}_{50}\right.$ of $\left.0.261 \mathrm{mg} / \mathrm{mL}\right)$ and L. kefiri JK17 $\left(\mathrm{IC}_{50}\right.$ of $\left.0.308 \mathrm{mg} / \mathrm{mL}\right)$. Results of peptide identification in the $<3 \mathrm{kDa}$ fraction showed that L. kefiri YK4 and L. kefiri JK17 could release peptides. The peptides produced were $95 \%$ derived from casein. A total of 30 peptides obtained in the present study have been recognized based on the literature searches as ACE-I peptides. L. kefiri YK4 and JK17 have the potential to be used as starter cultures in the production of bioactive ACE-I peptides. The two isolates could be used to support the strategies for promoting fermented milk products as a source of bioactive peptides that will benefit to health.

\section{Authors' Contributions}

LN, YTR, DI, and EP designed the research and experimental protocol. YTR carried out the research and data analyses. LN approved fermentation and analysis of the lactic acid bacteria. DI and EP approved analyses of angiotensin-converting enzyme and identification of peptides. YTR wrote the manuscript and LN corrected the manuscript. All the authors have read and approved the final version.

\section{Acknowledgments}

The author would like to thank the Indonesian Ministry of Research and Higher Education (RISTEKDIKTI) for providing research funding under the scheme of competitive-based research in 2018-2019 for the recipient Lilis Nuraida with the grant number 1609/IT3.11/PN/2018 for the year 2018 and 3/E1/KP.PTNBH/2019 for the year 2019.

\section{Competing Interests}

The authors declare that they have no competing interests.

\section{Publisher's Note}

Veterinary World remains neutral with regard to jurisdictional claims in published institutional affiliation.

\section{References}

1. Khan, I.T., Bule, M., Ullah, R., Nadeem, M., Asif, S. and Niaz, K. (2019) The antioxidant components of milk and their role in processing, ripening, and storage: Functional food. Vet. World, 12(1): 12-33.

2. Fitzgerald, R.J. and Murray B.A. (2006) Bioactive peptides and lactic fermentations. Int. J. Dairy Technol., 59(2): 118-125.

3. Pihlanto, A., Virtanen, T. and Korhonen, H. (2010) Angiotensin I converting enzyme (ACE) inhibitory activity and antihypertensive effect of fermented milk. Int. Dairy J., 20(1): 3-10.

4. Dallas, D.C., Citerne, F., Tian, T., Silva, V.L.M., Kalanetra, K.M., Frese, S.A., Robinson, R.C., Mills, D.A. and Barile, D. (2016) Peptidomic analysis reveals proteolytic activity of kefir microorganisms on bovine milk proteins. Food Chem., 197(4a): 273-284.

5. Lin, L., Lv, S. and Li, B. (2012) Angiotensin-I-converting enzyme (ACE)-inhibitory and antihypertensive properties of squid skin gelatin hydrolysates. Food Chem., 131(1): 225-230.

6. Zeng, Y., Wang, N. and Qian, W. (2013) Production of angiotensin I converting enzyme inhibitory peptides from peanut meal fermented with lactic acid bacteria and facilitated with protease. Adv. J. Food Sci. Technol., 5(9): 1198-1203.

7. Lin, Y.S., Lu, Y.L., Wang, G.J., Liang, H.J. and Hou, W.C. (2014) Vasorelaxing and antihypertensive activities of synthesized peptides derived from computer-aided simulation of pepsin hydrolysis of yam dioscorin. Bot. Stud., 55(1): 49. 
8. Gobbetti, M., Stepaniak, L., De Angelis, M., Corsetti A. and Di Cagno, R. (2002) Latent bioactive peptides in milk proteins: Proteolytic activation and significance in dairy processing. Crit. Rev. Food Sci. Nutr., 42(3): 223-239.

9. Luhovyy, B.L., Akhavan, T. and Anderson, G.H. (2007) Whey proteins in the regulation of food intake and satiety. J. Am. Coll. Nutr., 26(6): 704S-712S.

10. Akalin, S.A. (2014) Dairy-derived antimicrobial peptides: Action mechanisms, pharmaceutical uses and production proposals. Trends Food Sci. Technol., 36(2): 79-95.

11. Hartmann, R. and Meisel, H. (2007) Food-derived peptides with biological activity: From research to food applications. Curr. Opin. Biotechnol., 18(2): 163-169.

12. Chen, G.W., Tsai, J.S. and Pan, B.S. (2007) Purification of angiotensin I-converting enzyme inhibitory peptides and antihypertensive effect of milk produced by protease-facilitated lactic fermentation. Int. Dairy J., 17(6): 641-647.

13. Chen, Y., Liu, W., Xue, J., Yang, J., Chen, X., Shao, Y., Kwok, L.Y., Bilige, M., Mang, L. and Zhang H. (2014) Angiotensin-converting enzyme inhibitory activity of Lactobacillus helveticus strains from traditional fermented dairy foods and antihypertensive effect of fermented milk of strain H9. J. Dairy Sci., 97(11): 6680-6692.

14. Ahtesh, F.B., Stojanovska, L., Mathai, M.L., Apostolopoulos, V. and Mishra, V.K. (2016) Proteolytic and angiotensin-converting enzyme-inhibitory activities of selected probiotic bacteria. Int. J. Food Sci. Technol., 51(4): 865-874.

15. Griffiths, M.W. and Tellez, A.M. (2013) Lactobacillus helveticus: The proteolytic system. Front. Microbiol., 5(4): 30.

16. Sriphochanart, W. and Skolpap, W. (2010) Characterization of proteolytic effect of lactic acid bacteria starter cultures on Thai fermented sausages. Food Biotechnol., 24(4): 293-311.

17. Moreno-Montoro, M., Jauregi, P., Navarro-Alarcon, M., Olalla-Herrera, M., Gimenez-Martinez, R., Amigo, L and Miralles, B. (2018) Bioaccessible peptides released by in vitro gastrointestinal digestion of fermented goat milks. Anal. Bioanal. Chem., 410(15): 3597-3606.

18. Lunow, D., Kaiser, S., Rückriemen, J., Pohl, C. and Henle, T. (2015) Tryptophan-containing dipeptides are C-domain selective inhibitors of angiotensin-converting enzyme. Food Chem., 166(1): 596-602.

19. Nakamura, Y., Yamamoto, N., Sakai, K. and Takano, T. (1995) Antihypertensive effect of sour milk and peptides isolated from it that are inhibitors to angiotensin I-converting enzyme. J. Dairy Sci., 78(6): 1253-1257.

20. De Castro, R.J.S. and Sato, H.H. (2015) Biologically active peptides: Processes for their generation, purification and identification and applications as natural additives in the food and pharmaceutical industries. Food Res. Int., 74(8): 185-198.

21. Gonzalez-Gonzalez, C., Gibson, T. and Jauregi, P. (2013) Novel probiotic-fermented milk with angiotensin I-converting enzyme inhibitory peptides produced by Bifidobacterium bifidum MF 20/5. Int. J. Food Microbiol.,167(2): 131-137.

22. Solieri, L., De Vero, L. and Tagliazucchi, D. (2018) Peptidomic study of casein proteolysis in bovine milk by Lactobacillus casei PRA205 and Lactobacillus rhamnosus PRA331. Int. Dairy J., 85(10): 237-246.

23. Bradford, M.M. (1976) A rapid and sensitive method for the quantitation microgram quantities of protein utilizing the principle of protein-dye binding. Anal. Biochem., 72(1-2): 248-254.

24. Chusman, D.W. and Cheung H.S. (1971) Spectrophotometric assay and properties of the angiotensin-converting enzyme of rabbit lung. Biochem. Pharmacol., 20(7): 1637-1648.

25. Daliri, E.B.M., Lee, B.H., Kim, J.H. and Oh, D.H. (2018) Novel angiotensin I-converting enzyme inhibitory peptides from soybean protein isolates fermented by Pediococcus pentosaceus SDL1409. Lwt Food Sci. Technol., 93(7): 88-93.

26. Ibrahim, H.R., Ahmed, A.S. and Miyata, T. (2017) Novel angiotensin-converting enzyme inhibitory peptides from caseins and whey proteins of goat milk. J. Adv. Res., 8(1): 63-71.

27. Fan, M., Guo, T., Li, W., Chen, J., Li, F., Wang, C., Shi, Y.,
X-An, D. Zhang, S. (2019), Isolation and identification of novel casein-derived bioactive peptides and potential functions in fermented casein with Lactobacillus helveticus. Food Sci. Hum. Wellness, 8(2): 156-176.

28. Gobbetti, M., Ferranti, P., Smacchi, E., Goffredi, F. and Addeo, F. (2000) Production of angiotensin-I-converting-enzyme-inhibitory peptides in fermented milks started by Lactobacillus delbrueckii subsp. bulgaricus SS1 and Lactococcus lactis subsp. cremoris FT4. Appl. Environ. Microbiol., 66(9): 3898-3904.

29. Papadimitriou, C.G., Vafopoulou-Mastrojiannaki, A., Silva, S.V., Gomes, A.M., Malcata, F.X. and Alichanidis, E. (2007) Identification of peptides in traditional and probiotic sheep milk yoghurt with angiotensin I-converting enzyme (ACE)-inhibitory activity. Food Chem., 105(2): 647-656.

30. Amorim, M., Marques, C., Pereira, J.O., Guardao, L., Martins, M.J., Osorio, H., Moura, D., Calhau, C., Pinheiro, H. and Pintado, M. (2019) Antihypertensive effect of spent brewer yeast peptide. Process Biochem., 76(1): 213-218.

31. Contreras, M. del Mar, Carron, R., Montero, M.J., Ramos, M. and Recio, I. (2009) Novel casein-derived peptides with antihypertensive activity. Int. Dairy J., 19(10): 566-573.

32. Gómez-Ruiz, J.Á., Ramos, M. and Recio, I. (2002) Angiotensin-converting enzyme-inhibitory peptides in Manchego cheeses manufactured with different starter cultures. Int. Dairy J., 12(8): 697-706.

33. Torres-Llanez, M.J., González-Córdova, A.F., HernandezMendoza, A., Garcia, H.S. and Vallejo-Cordoba, B. (2011) Angiotensin-converting enzyme inhibitory activity in Mexican fresco cheese. J. Dairy Sci., 94(8): 3794-3800.

34. Hernandes-Ledesma, B., Amigo, L., Ramos, M. and Recio, I. (2004) Angiotensin-converting enzyme inhibitory activity in commercial fermented products. Formation of peptides under simulated gastrointestinal digestion. $J$. Agric. Food Chem., 52(6): 1504-1510.

35. Hayes, M., Stanton, C., Salttery, H., Sullivan, O.O., Hill, C., Fitzgerald, G.F. and Ross, R.P. (2007) Casein fermentate of Lactobacillus animalis DPC6134 contains a range of novel propeptide angiotensin-converting enzyme inhibitors. Appl. Environ. Microbiol., 73(14): 4658-4667.

36. Villegas, J.M., Picariello, G., Mamone, G., Turbay, M.B.E., Savoy de Giori, G. and Hebert, E.M. (2014) Milk-derived angiotensin-I-converting enzyme inhibitory peptides generated by Lactobacillus delbrueckii subsp. Lactis CRL 581. Peptidomics, 1(1): 22-29.

37. Perpetuo, E.A., Juliano, L. and Lebrun, I. (2003) Biochemical and pharmacological aspects of two bradykinin-potentiating peptides obtained from tryptic hydrolysis of casein. J. Protein Chem., 22(7/8): 601-606.

38. Zhao, H., Zhou, F., Wang, L., Fengling, B., Dziugan, P., Walczak, P. and Zhang, B. (2014) Characterization of a bioactive peptide with cytomodulatory effect released from casein. Eur. Food Res. Technol., 238(2): 315-322.

39. Zhao, Y.Q., Zhang, L., Tao, J., Chi, C.F. and Wang, B. (2019) Eight antihypertensive peptides from the protein hydrolysate of Antarctic krill (Euphausia superba): Isolation, identification, and activity evaluation on human umbilical vein endothelial cells (HUVECs). Food Res. Int., 121(7): 197-204.

40. Rodríguez-Figueroa, J.C., González-Córdova, A.F., TorresLlanez, M.J., Garcia, H.S. and Vallejo-Cordoba, B. (2012) Novel angiotensin I-converting enzyme inhibitory peptides produced in fermented milk by specific wild Lactococcus lactis strains. J. Dairy Sci., 95(10): 5536-5543.

41. Yamamoto, N., Akino, A. and Takano, T. (1994) Antihypertensive effect of the peptides derived from casein by an extracellular proteinase from Lactobacillus helveticus CP790. J. Dairy Sci., 77(4): 917-922.

42. Gútiez, L., Gomez-Sala, B., Recio, I., del Campo, R., Cintas, L.M., Herranz, C. and Hernandez, P.E. (2013) 
Enterococcus faecalis strains from food, environmental, and clinical origin produce ACE-inhibitory peptides and other bioactive peptides during growth in bovine skim milk. Int. J. Food Microbiol., 166(1): 93-101.

43. Solanki, D., Hati, S. and Sakure, A. (2017) In silico and in vitro analysis of novel angiotensin I-converting enzyme (ACE) inhibitory bioactive peptides derived from fermented camel milk (Camelus dromedarius). Int. J. Pept. Res. Ther., 23(4): 441-459.

44. Wu, J., Xie, D., Chen, X., Tang, Y.J., Wang, L., Xie, J. and Wei, D. (2019) Inhibitory mechanism of a substrate-type angiotensin I-converting enzyme inhibitory peptide. Process Biochem., 79(4): 97-104.

45. Elkhtab, E., El-Alfy, M., Shenana, M., Mohamed, A. and Yousef, A.E. (2017) New potentially antihypertensive peptides liberated in milk during fermentation with selected lactic acid bacteria and kombucha cultures. J. Dairy Sci., 100(12): 9508-9520.

46. Donkor, O.N., Henriksson, A., Singh, T.K., Vasiljevic, T. and Shah, N.P. (2007) ACE-inhibitory activity of probiotic yoghurt. Int. Dairy J., 17(11): 1321-1331.

47. Wang, J., Li, C., Xue, J., Yang, J., Zhang, Q., Zhang, H. and Chen, Y. (2015) Fermentation characteristics and angiotensin I-converting enzyme inhibitory activity of Lactobacillus helveticus isolate H9 in cow milk, soy milk, and mare milk. J. Dairy Sci., 98(6): 3655-3664.

48. Wu, N., Xu, W., Liu, K., Xia, Y. and Shuangquan. (2019) Angiotensin-converting enzyme inhibitory peptides from Lactobacillus delbrueckii QS306 fermented milk. J. Dairy Sci., 102(7): 5913-5921.

49. Rodríguez-Figueroa, J.C., Reyes-Diaz, R., GonzalezCordova, A.F., Troncoso-Rojas, R., Vargas-Arispuro, I. and Vallejo-Cordoba, B. (2010) Angiotensin-converting enzyme inhibitory activity of milk fermented by wild and industrial Lactococcus lactis strains. J. Dairy Sci., 93(11): 5032-5038.

50. Fuglsang, A., Rattray, F.P., Nilsson, D. and Nyborg, N.C. (2003) Lactic acid bacteria: Inhibition of angiotensin-converting enzyme in vitro and in vivo. Antonie van Leeuwenhoek. Int.J.Gen.Mol. Microbiol., 83(1): 27-34.

51. Quirós, A., Ramos, M., Muguerza, B., Delgado, M.A., Miguel, M., Aleixander, A. and Recio, I. (2007) Identification of novel antihypertensive peptides in milk fermented with Enterococcus faecalis. Int. Dairy J., 17(1): 33-41.

52. Qian, B., Xing, M., Cui, L., Deng, Y., Xu, Y., Huang, M. and Zhang, S. (2011) Antioxidant, antihypertensive, and immunomodulatory activities of peptide fractions from fermented skim milk with Lactobacillus delbrueckii ssp. bulgaricus
LB340. J. Dairy Res., 78(1): 72-79.

53. Moslehishad, M., Ehsani, M.R., Salami, M., Mirdamadi, S., Ezzatpanah, H., Naslaji, A.N. and Movahedi, A.A.M. (2013) The comparative assessment of ACE-inhibitory and antioxidant activities of peptide fractions obtained from fermented camel and bovine milk by Lactobacillus rhamnosus PTCC 1637. Int. Dairy J., 29(2): 82-87.

54. Chen, Y., Wang, Z., Chen, X., Liu, Y., Zhang, H. and Sun, T. (2010) Identification of angiotensin I-converting enzyme inhibitory peptides from koumiss, a traditional fermented mare's milk. J. Dairy Sci., 93(3): 884-892.

55. Li, C., Kwok, L.Y., Mi, Z., Bala, J., Xue, J., Yang, J., Ma, Y., Zhang, H. and Chen, Y. (2017) Characterization of the angiotensin-converting enzyme inhibitory activity of fermented milks produced with Lactobacillus casei. J. Dairy Sci., 100(12): 9495-9507.

56. Svanborg, S., Johansen, A.G., Abrahamsen, R.K. and Skeie, S.B. (2015) The composition and functional properties of whey protein concentrates produced from buttermilk are comparable with those of whey protein concentrates produced from skimmed milk. J. Dairy Sci., 98(9): 5829-5840.

57. Wu, J., Aluko, R.E. and Nakai, S. (2006) Structural requirements of angiotensin I-converting enzyme inhibitory peptides: Quantitative structure-activity relationship modeling of peptides containing 4-10 amino acid residues. J. Agric. Food Chem., 54(3): 732-738.

58. Minervini, F., Algaron, F., Rizzello, C.G., Fox, P.F., Monnet, V. and Gobetti, M. (2003) Angiotensin I-converting-enzyme-inhibitory and antibacterial peptides from Lactobacillus helveticus PR4 Proteinase-hydrolyzed caseins of milk from six species. Appl. Environ.Microbiol., 69(9): 5297-5305.

59. Lignitto, L., Cavatorta, V., Balzan, S., Gabai, G., Galaverna, G., Novelli, E., Sforza, S. and Segato, S. (2010) Angiotensin-converting enzyme inhibitory activity of water-soluble extracts of Asiago d'allevo cheese. Int. Dairy J., 20(1): 11-17.

60. Fan, H., Liao, W. and Wu, J. (2018) Molecular interactions, bioavailability, and cellular mechanisms of angiotensin-converting enzyme inhibitory peptides. J. Food Biochem., 43(1): 1-8.

61. Ebner, J., Arslan, A.A., Fedorova, M., Hoffmann, R., Kucukcetin, A. and Pischetsrieder, M. (2015) Peptide profiling of bovine kefir reveals 236 unique peptides released from caseins during its production by starter culture or kefir grains. J. Proteomics, 117(6): 41-57.

\section{$* * * * * * * *$}

